\title{
Urgent splenectomy in the course of prosthetic valve endocarditis
}

\author{
Anna Marcinkiewicz ${ }^{1}$, Stanisław Ostrowski², Witold Pawłowski², Artur Palczak ${ }^{3}$, \\ Anna Adamek-Kośmider ${ }^{1}$, Ryszard Jaszewski ${ }^{2}$ \\ ${ }^{1}$ Military Medical Academy University Teaching Hospital - Central Veterans' Hospital in Łódź, Poland \\ ${ }^{2}$ Cardiac Surgery Clinic, Chair of Cardiology and Cardiac Surgery, Medical University of Łódź, Poland \\ ${ }^{3}$ Department of Gastroenterological, Oncological, and General Surgery, Norbert Barlicki University Hospital, Medical University \\ of tódź, Poland
}

Kardiochirurgia i Torakochirurgia Polska 2014; 11 (2): 205-209

\begin{abstract}
We present a case of a 51-year-old male patient hospitalized due to acute coronary syndrome requiring stent implantation to the left main stem. Double antiplatelet therapy was commenced. After 2-3 days, the patient presented with high fever, dyspnea on exertion, pain in the chest, myalgia, and general weakness. Transthoracic (TTE) and transesophageal (TEE) echocardiography revealed abnormal, turbulent flow across the aortic prosthesis, which was probably caused by the presence of a pathological smooth and mobile structure $(10 \times 9$ $x 5 \mathrm{~mm}$ ) in front of the aortic annulus. Blood cultures were positive and staphylococcal prosthetic valve endocarditis (PVE) was diagnosed. Despite antibiotic treatment, the patient's condition deteriorated, and he was referred for prosthesis reimplantation. After being transferred to the Cardiac Surgery Clinic, he presented with nausea, vomiting, and abdominal pain. The results of imaging examinations suggested spleen hematoma. The patient underwent an urgent splenectomy. Histopathological examination revealed a spleen infarction consequent to an embolic event and subscapular hematoma. On the $10^{\text {th }}$ day after the laparotomy, cardiac surgery was performed. No large vegetations were found on the aortic prosthesis. The mechanical valve, implanted 20 years earlier, was functioning properly; it was intact and well healed. Several fragments of a thrombus and fibrous tissue, resembling a pannus and covered with minor calcifications, were removed from the ventricular surface of the discs. A decision was reached to leave the aortic prosthesis in situ. The valvular material culture revealed the presence of Streptococcus anginosus, and the antibiotic scheme was modified. The postoperative period was uneventful.

Key words: embolization, splenic infarction, hematoma.
\end{abstract}

\section{Streszczenie}

W pracy przedstawiono przypadek pęknięcia śledziony w przebiegu infekcyjnego zapalenia wsierdzia (IZW). Śledziona jest jednym z najczęściej zajętych narządów w przebiegu IZW, z czego część przypadków pozostaje niemych klinicznie. Pęknięcie śledziony to rzadkie powikłanie IZW, ale wiąże się z wysoką śmiertelnością i wymaga pilnej interwencji chirurgicznej. Opisany pacjent prezentował niezbyt nasilone objawy w postaci bólów brzucha, nudności i wymiotów. Oprócz IZW i sztucznej zastawki pacjent miał zwężenie pnia lewej tętnicy wieńcowej, będące przyczyną ostrego zespołu wieńcowego w okresie przedoperacyjnym i wymagające implantacji stentu. Do pęknięcia śledziony doszło na podłożu zatorowości i zawału w obrębie narządu. W czasie zabiegu kardiochirurgicznego na protezie aortalnej nie znaleziono żadnych wegetacji, a sama proteza, wszczepiona 20 lat wcześniej, funkcjonowała prawidłowo. Była nieuszkodzona i dobrze wgojona, dlatego podjęto decyzję o jej pozostawieniu. Pooperacyjny stan kliniczny pacjenta i wykonane badanie echokardiograficzne potwierdziło korzystny efekt takiego postępowania.

Słowa kluczowe: zatorowość, zawał śledziony, krwiak.

Address for correspondence: lek. Anna Marcinkiewicz, Military Medical Academy University Teaching Hospital - Central Veterans' Hospital in Łódź, Poland, tel. +48 4263315 58, e-mail: annamar87@o2.pl 


\section{Introduction}

Embolic complications occur in $12-40 \%$, or even as many as $21-50 \%$ of infective endocarditis (IE) cases [1, 2]. $75 \%$ of them occur before the introduction of appropriate antibiotic therapy [3]. During the course of antibiotic treatment, the risk of complications is reduced significantly; it is estimated at $6-21 \%$ and remains particularly high during the first two weeks of treatment $[1,4]$. Therefore, if surgery is planned in order to prevent further embolic episodes, it should be conducted as soon as possible. The most common location of embolism formation in left-sided IE is the central nervous system. Among the parenchymal organs of the abdominal cavity, the spleen is the most common location of embolisms, primarily due to its anatomical characteristics. It is estimated that the spleen is involved in $5-12 \%$ of IE cases [5]. Similarly, clinically silent embolisms appear most often in the two aforementioned locations. The factors predisposing to peripheral embolism formation include: large (>10 mm) and mobile vegetations, mitral valve endocarditis, history of embolic events, increased or reduced vegetation size during antibiotic therapy, and specific IE etiology, staphylococcal infections in particular.

Infected embolic material from intracardiac vegetations can also contribute to splenic abscess formation, which happens in approximately $5 \%$ of IE cases $[6,7]$, or to the occurrence of a splenic infarction. Furthermore, mycotic aneurysms may appear in the course of IE; they account for approximately $10 \%$ of splenic artery aneurysms and are related to a more than 10 times higher risk of rupture than the other aneurysms of the splenic artery [8]. The chronic inflammatory process associated with IE can result in amyloidosis. Thirty-one cases of localized amyloidosis secondary to endocardial infection have been described [9]. All these conditions, or even splenomegaly itself, can be associated with spleen rupture, which is a very serious, although rare, complication of IE. This condition is burdened with high mortality reaching $58 \%$ [10].

This article presents the case of an urgent surgical intervention performed on a patient diagnosed with infective endocarditis of a prosthetic aortic valve, who was admitted to the Cardiac Surgery Clinic in Lodz in order to undergo surgical treatment.

\section{Case study}

The 51-year-old patient was admitted to the Cardiac Surgery Clinic in Lodz with the diagnosis of coronary artery disease and infective endocarditis of the aortic prosthesis (St. Jude 23A), which was implanted 20 years earlier due to a complex aortic defect presenting mainly as aortic stenosis. In addition, the patient's medical history included stage I arterial hypertension, stage III chronic kidney disease, and hyperuricemia.

The diagnosis of prosthetic valve endocarditis was made one month earlier, while the patient was hospitalized for acute coronary syndrome (ACS). At the time, he exhibited typical signs of unstable angina. On admission, the patient complained of exercise tolerance deterioration, easy fatigability, dyspnea, palpitations, as well as periodically observed increases of blood pressure and body temperature, which had persisted for 6 months. A decision was undertaken to perform a coronary angiographic examination and a percutaneous coronary intervention ( $\mathrm{PCI})$, during which a bare-metal stent (BMS) was implanted into the left main coronary artery. Furthermore, an independent stenosis was visualized in the proximal segment of the left anterior descending artery (70-90\%, atherosclerotic plaque). Echocardiography carried out at that time revealed normal cardiac contractility with ejection fraction (EF) at $65 \%$ and slight fibrosis of the mitral leaflets and chordae tendineae with non-significant mitral regurgitation. Examination of the aortic prosthesis revealed two regurgitation jets - central and lateral. The maximum gradient across the mechanical aortic valve was $54 \mathrm{mmHg}$, and the mean gradient was $30 \mathrm{mmHg}$. After 2-3 days following the stent implantation, the patient presented with high fever, dyspnea on exertion, chest pain, myalgia, and general weakness. On the basis of transthoracic (TTE) and transesophageal (TEE) echocardiography as well as positive blood cultures, in which Staphylococcus aureus was found, the diagnosis of prosthetic valve endocarditis was made. This time, the echocardiographic examinations revealed abnormal, turbulent flow across the aortic prosthesis, which was probably caused by the presence of a pathological smooth and mobile structure $(10 \times$ $9 \times 5 \mathrm{~mm}$ ) in front of the aortic annulus. Roentgenoscopy was also performed, showing proper disc mobility. Initially, empirical antibiotic treatment was introduced (ampicillin with sulbactam and gentamicin). Despite employing proper intravenous antibiotic therapy in accordance with the antibiogram and the guidelines for antibiotic treatment in prosthetic valve endocarditis of staphylococcal etiology (cloxacillin, rifampicin, gentamicin), the patient's clinical condition deteriorated, as lower limb edema, dyspnea, and fever progressed, and abdominal circumference increased. Abdominal ultrasound showed only a slight enlargement of the spleen (approx. $15 \mathrm{~cm}$ in length) without focal lesions. The patient was initially qualified for surgical myocardial revascularization and prosthetic aortic valve replacement. Clopidogrel and acenocoumarol were stopped, and low-molecular-weight heparin LMWH (Clexane $2 \times 60 \mathrm{mg}$ s.c.) was commenced. Acetylsalicylic acid was continued.

After being admitted to the Cardiac Surgery Clinic due to slight abdominal pain, nausea, and vomiting persisting for 2 days, the patient underwent abdominal ultrasound, which revealed an irregular area of increased echogenicity $(140 \times 120 \times 40 \mathrm{~mm}$ in size), likely to be a hematoma, on the lateral outline of the spleen and the left hypochondriac region. A similar focus of comparable echogenicity and size $(100 \times 90 \times 40 \mathrm{~mm})$ was found on the posterior outline of the right liver lobe, and a smaller subcapsular focus (16 mm in thickness) was found on the anterior outline of the right liver lobe. The patient denied any trauma. He was transferred to the general surgery department for further diagnosis. The performed CT scan confirmed the presence of significant effusion in both pleural cavities and a hemato- 
ma of the spleen and its surroundings $(160 \times 50 \times 50 \mathrm{~mm})$, which extended along the length of $12 \mathrm{~cm}$. Another hematoma was visualized at the base of the right lobe of the liver $(100 \times 90 \times 40 \mathrm{~mm})$, and effusion was found in the peritoneal cavity, in the lumbar region and the lower abdomen. The patient underwent urgent laparotomy. Intraoperatively, a significant subcapsular rupture of the phrenic surface within the spleen was found, along with a large hematoma. Splenectomy was performed, and the excised spleen was sent to the laboratory for histopathological examination. The liver was inspected intraoperatively; although a significant amount of blood infiltrated the right liver lobe and lesser omentum, no liver parenchymal injury was found. Approximately $800 \mathrm{~mL}$ of free blood was evacuated from the peritoneal cavity. Microscopic evaluation of the intraoperatively obtained splenic section revealed a splenic infarction with a subcapsular hematoma.

On the $10^{\text {th }}$ day after the splenectomy, the patient underwent cardiac surgery. Before the surgery, TTE and TEE examinations were conducted; they visualized the prosthetic aortic valve with minor additional echoes from calcified vegetations. The maximum gradient across the aortic prosthesis was $74 \mathrm{mmHg}$ and the mean was $41 \mathrm{mmHg}$. The peak velocity across the aortic prosthesis was $4.3 \mathrm{~m} / \mathrm{s}$. Slight aortic insufficiency was present. Good systolic function of the left ventricle was confirmed, without any regional contractility disturbances and with EF at $61 \%$. A small amount of pericardial effusion was visualized up to $1.5 \mathrm{~cm}$ behind the lateral wall, and a significant amount of fluid was found in the left pleural cavity. The procedure was then conducted via median sternotomy, under extracorporeal circulation, with the use of intermittent antegrade crystalloid cardioplegic solution $(950 \mathrm{~mL})$ for cardiac protection. Firstly, the left internal thoracic artery was anastomosed with the left anterior descending artery. Then, the aorta was opened with a transverse excision, and the mechanical valve was visualized. The aortic prosthesis was intact and well healed. Several fragments of a thrombus and fibrous tissue, resembling a pannus and covered with minor calcifications, were removed from the ventricular surface of the discs. The material was sent for culture. A decision was made to leave the aortic prosthesis in situ. Intraoperatively, $1100 \mathrm{~mL}$ of fluid was evacuated from the left pleural cavity and $600 \mathrm{~mL}$ from the right pleural cavity. Aortic cross clamping time was $33 \mathrm{~min}$, and total cardiopulmonary bypass time was $51 \mathrm{~min}$. The patient was extubated on the same day. On the $2^{\text {nd }}$ postoperative day, he was discharged from the intensive care unit and transferred to the cardiac department for the continuation of the antibiotic therapy for prosthetic valve endocarditis (complete 6 weeks of treatment). The patient remained in good condition, without any complaints. The culture of the valvular material revealed the presence of Streptococcus anginosus. The antibiotic treatment was modified in accordance with the obtained antibiogram (vancomycin). A control abdominal ultrasound revealed a normoechogenic, homogeneous liver. Postoperative echocardiography showed that the aortic valve prosthesis was functioning properly, revealing two slight structure-related jets. The peak velocity across the valve was $2.8 \mathrm{~m} / \mathrm{s}$. The maximum gradient was $32 \mathrm{mmHg}$ and the mean was $18 \mathrm{mmHg}$. The examinations also revealed apical hypokinesia and hypokinesia of the para-apical and middle segments of the interventricular septum and the anterior wall of the left ventricle with a minor decrease of EF to $42 \%$. A small amount of fluid was found in the pericardial sac (up to $0.9 \mathrm{~cm}$ ). The subsequent course of the treatment was uneventful. After the surgery, the LMWH therapy was prolonged by several days, and oral anticoagulation was gradually introduced. At first, the patient received bridge therapy, and acenocoumarol was resumed; then, clopidogrel was included in the treatment.

\section{Discussion}

Prosthetic valve endocarditis is a factor which seriously worsens the patient's prognosis (with mortality even up to $40 \%$ ) [11], as is the case with peripheral embolisms and unfavorable etiology (S. aureus). Considering the unfavorable characteristics of the patient and his deteriorating clinical condition, as well as the size of the vegetation $(10 \times 9 \times 5 \mathrm{~mm})$, it was decided to conduct an early cardiac surgical intervention, which, in the context of the subsequent spleen rupture, proved to be the most reasonable decision. The intraoperative decision to leave the prosthesis in situ was extremely difficult, especially in the context of $S$. aureus virulence, the weak response to the preoperative targeted antibiotic therapy (deterioration of clinical condition), and the course of endocarditis complicated by the spleen rupture. On the other hand, the intraoperative image of the non-active infection, the proper functioning of the prosthesis, the potential damage to the aortic annulus during valve removal, as well as the fact that the $S$. aureus strain was methicillin-sensitive constituted arguments for leaving the well-healed mechanical valve, implanted 20 years earlier, in place.

The estimated incidence of spleen involvement in the course of IE is $4.8-35 \%$ [12]. The first case of splenic rupture as a complication of IE was reported in 1919 by Lake et al. [13]. Splenic rupture secondary to endocardial infection carries a high mortality rate. Rapid development of hypovolemic shock symptoms is often preceded by an asymptomatic period [10,14], especially if the atraumatic rupture of the spleen is a result of its infarction in the course of IE [15]. In the case of our patient, the symptoms were also scarce and included abdominal pain, nausea, and vomiting. The histopathological results indicated that the embolic material from vegetations caused localized ischemia of the spleen with a subsequent delayed subcapsular rupture of the organ, which probably saved the patient's life. In the context of barely symptomatic, clinically silent episodes of spleen embolism, or even its rupture, the role of periodical, but systematically performed, abdominal imaging examinations (CT or ultrasound) should be underlined as well, as it is emphasized in the guidelines on the diagnosis and treatment of IE [1]. It should be noted that the initial abdominal ultra- 
sound revealed no focal lesions in the spleen, only its slight enlargement. However, splenomegaly may reflect the presence of a chronic subacute inflammatory process, lasting at least 10 days [11]. Computed tomography (CT) performed at that time would have probably visualized an ischemic focus in the organ. The literature reports that atraumatic spleen rupture is detected during laparotomy in $42.3 \%$, by CT scans in $32.4 \%$, and by ultrasound in $18.6 \%$ of cases [16]. At this point, the indications for splenectomy in the case of splenic lesions secondary to an IE process should be listed. These include primarily spleen rupture, large lesions in the form of infarctions or abscesses with diameters of more than $2 \mathrm{~cm}$, peripheral lesions, and persistent symptoms of sepsis. Infarcts that are asymptomatic, small, and centrally located do not require intervention; notwithstanding, even asymptomatic lesions that are large or localized peripherally require careful monitoring with repeated CT scans $[11,17]$. The length of the hospitalization period between splenectomy and cardiac surgery is also worth considering. Patients after splenectomies are exposed to a number of complications associated with anemia resulting from perioperative blood loss as well as numerous gastroenterological complications, especially paralytic ileus; furthermore, patients with asplenia are at an increased risk of infection. The hospitalization period after elective splenectomy usually does not exceed 2-4 days, but is prolonged slightly in the case of urgent or emergent interventions. Splenectomy is rarely performed in the case of splenic rupture secondary to IE. The postoperative course is typically dependent on patient characteristics and the course of the endocarditis due to the lack of any other injuries. In our case, a 10-day interval allowed us to stabilize the patient's status without delaying the cardiac surgery in a significant manner. In the course of endocarditis, splenic rupture can occur even if the affected valve (i.e. the source of infection) is removed or if antibiotic treatment is introduced. It should, however, be stressed that the use of heparin or vitamin $\mathrm{K}$ antagonists may contribute to the occurrence of this complication [17]. The use of anticoagulation (artificial valve) and double antiplatelet therapy (ACS with stent implantation) in our patient could have caused a secondary hemorrhage within the splenic infarct.

Atraumatic splenic rupture is most commonly caused by hematological diseases, mainly acute leukemia [18]. It may also be a result of pancreatitis or be related to the received medication [16]. In the practice of cardiac surgery, splenic rupture has been reported as a result of an intraoperative injury of the splenic hilum during transesophageal echocardiography [19]. Moreover, it may be secondary to acute pancreatitis after coronary artery bypass grafting [20]. Other possible causes of this condition should always be taken into consideration.

In the literature, the frequency of positive blood cultures in IE varies widely from $45 \%$ [21] to $84 \%$ [22]. According to our own observations, positive cultures are found in $45 \%$ of cases [23], while cultures from valvular material allow this percentage to be increased to approximately $60 \%$
[24]. According to other authors, the frequency of positive blood cultures from materials obtained intraoperatively or embolic materials is estimated at 70\% [25]. Still others suggest that cultures from valvular material are positive in only $10-15 \%$ of cases [26]. These data, however, refer to patients operated on in non-active stages of infection after undergoing antibiotic therapy. In our patient, two potential clinical scenarios should be considered. On the one hand, the infection could have been caused by two pathogens: Staphylococcus aureus and Streptococcus anginosus [27-29]. The use of proper targeted antibiotic therapy, to which the strain obtained from the blood cultures (Staphylococcus aureus) was sensitive, promoted the growth of the second bacterial strain and its identification in the valvular material. The fact that the culture of the valvular material was positive for Streptococcus anginosus indicates that the previous antibiotic therapy had been ineffective in eliminating this pathogen, and that a complete 6-week scheme of intravenous antibiotic treatment in accordance with the antibiogram should be commenced after surgery. In such a situation, it is important to carry out a complete antibiotic treatment scheme, targeting both microorganisms. On the other hand, it appears probable that late prosthetic valve endocarditis caused by $S$. anginosus with a subacute course (intermittent increased temperature during 6 months before the first hospitalization and non-active stage of the infection, as indicated by intraoperative examination) was accompanied by bacteremia associated with $\mathrm{PCI}$. In view of immunological disturbances in the course of IE, it can be suspected that bacteremia caused by a pathogen as virulent as Staphylococcus aureus could have promoted rapid growth of the vegetations (an interval of 2-3 days between the echocardiographic examinations conducted on admission due to ACS and after the onset of high temperature).

In a 30-day follow-up, the patient remains in good condition. He is receiving combined antiplatelet and anticoagulant therapy.

It should, however, be noted that any patient after splenectomy with an implanted mechanical heart valve and after an IE episode is at very high risk of both a generalized infection with sepsis and a potential subsequent IE episode of variable, sometimes even less common etiology. Hence, such patients should receive meticulous outpatient care, including protective vaccines against Streptococcus pneumoniae, Haemophilus influenzae, and Neisseria meningitidis in particular [6], and any invasive procedures that they undergo, including dental treatments or cosmetic procedures, should be conducted under antibiotic protection.

\section{Conclusions}

Splenic rupture is a rare, but very dangerous complication of infective endocarditis, which should be considered in view of any abdominal complaints. Risk factors of peripheral embolization, which is the principal mechanism of focal lesion formation in the spleen, predispose to splenic rupture as well, as does the administration of anticoagulant and antiplatelet medications. It appears that CT should 
be the examination of choice on suspicion of pathological abdominal processes in the course of IE. The decision to perform a cardiac surgical intervention without delay protected our patient from further embolic complications, and it allowed us to leave in place the mechanical valve implanted 20 years earlier and achieve a good surgical outcome. Considering the patient's current condition - he is expected to complete the antibiotic treatment shortly and his general condition continues to be good - it appears that the conducted cardiac surgical procedure was optimal for his well-being.

\section{References}

1. Habib G, Hoen B, Tornos P, Thuny F, Prendergast B, Vilacosta I, Moreillon P, de Jesus Antunes $M$, Thilen $U$, Lekakis J, Lengyel M, Müller L, Naber CK, Nihoyannopoulos P, Moritz A, Zamorano JL; ESC Committee for Practice Guidelines. Guidelines on the prevention, diagnosis, and treatment of infective endocarditis (new version 2009): the Task Force on the Prevention, Diagnosis, and Treatment of Infective Endocarditis of the European Society of Cardiology (ESC). Endorsed by the European Society of Clinical Microbiology and Infectious Diseases (ESCMID) and the International Society of Chemotherapy (ISC) for Infection and Cancer. Eur Heart J 2009; 30: 2369-2413.

2. Colen TW, Gunn M, Cook E, Dubinsky T. Radiologic manifestations of extra-cardiac complications of infective endocarditis. Eur Radiol 2008; 18: 2433-2445.

3. Ganz NM, Brown RB, Berk SL, Mayers JW. Manual of Clinical Problems in Infectious Diseases. $5^{\text {th }}$ ed. Lippincott Williams \& Wilkins, Philadelphia 2006, p. 56.

4. Habib G, Badano L, Tribouilloy C, Vilacosta I, Zamorano JL, Galderisi M, VoigtJU, Sicari R, Cosyns B, Fox K, Aakhus S; European Association of Echocardiography. Recommendations for the practice of echocardiography in infective endocarditis. Eur J Echocardiogr 2010; 11: 202-219.

5. Fernandez Guerrero ML, Goyenechea A, Verdejo C, Roblas RF, de Gorgolas M. Enterococcal endocarditis on native and prosthetic valves: a review of clinical and prognostic factors with emphasis on hospital-acquired infections as a major determinant of outcome. Medicine (Baltimore) 2007; 86: 363-377.

6. Simsir SA, Cheeseman SH, Lancey RA, Vander Salm TJ, Gammie JS. Staged laparoscopic splenectomy and valve replacement in splenic abscess and infective endocarditis. Ann Thorac Surg 2003; 75: 1635-1637.

7. Lester SJ, Wilansky S. Endocarditis and associated complications. Crit Care Med 2007; 35: S384-391.

8. Eng CW, Venkatesh SK. Clinics in diagnostic imaging (131). Multiple visceral mycotic aneurysms. Singapore Med J 2010; 51: 824-830.

9. Renzulli P, Schoepfer A, Mueller E, Candinas D. Atraumatic splenic rupture in amyloidosis. Amyloid 2009; 16: 47-53.

10. Winearls JR, McGloughlin S, Fraser JF. Splenic rupture as a presenting feature of endocarditis. Eur J Cardiothorac Surg 2009; 35: 737-739.
11. Khan MF, Ghani S. Infective endocarditis complicated by splenic rupture and fatal intra-abdominal haemorrhage. BMJ Case Rep 2009; 2009: bcr01.2009.1460.

12. Méndez ML, Vilacosta I, Sarriá C, Fernández C, San Román JA, Sanmartín JV, López J, Rodrígueze E. Hepatosplenic and renal embolisms in infective endocarditis. Rev Esp Cardiol 2004; 57: 1188-1196.

13. Lake NC, Kevin HK, Irel S. Three uncommon abdominal cases illustrating some pitfalls. Lancet 1919; 2: 13.

14. Baibars M, Ohrum P, Alraiyes AH, Alraies MC. Asymptomatic spleen rupture in patient with endocarditis. QJM 2013; 106: 1047-1048.

15. Ting W, Silverman NA, Arzouman DA, Levitsky S. Splenic septic emboli in endocarditis. Circulation 1990, 82: 105-109.

16. Renzulli P, Hostettler A, Schoepfer AM, Gloor B, Candinas D. Systematic review of atraumatic splenic rupture. Br J Surg 2009; 96: 1114-1121.

17. Dimitrakakis G, Von Oppell U, Zilidis G, Srivastava A. Splenic rupture complicating aortic valve replacement for bacterial endocarditis. Interact Cardiovasc Thorac Surg 2008; 7: 138-140.

18. Rhee SJ, Sheena Y, Imber C. Spontaneous rupture of the spleen: a rare but important differential of an acute abdomen. Am J Emerg Med 2008; 26: 733.e5-6.

19. Olenchock SA Jr, Lukaszczyk JJ, Reed J $3^{\text {rd }}$, Theman TE. Splenic injury after intraoperative transesophageal echocardiography. Ann Thorac Surg 2001; 72: 2141-2143.

20. Pilkey RM, Lawrence MD, Wolfsohn AL, Walley VM. Splenic rupture resulting from acute pancreatitis after cardiac surgery with intra-aortic balloon pumping: case report. Can J Surg 1994; 37: 428-429.

21. Begezsán II, Dorobăț CM. Diagnostic approaches in infective endocarditis. Rev Med Chir Soc Med Nat lasi 2012; 116: 108-113.

22. Leblebicioglu H, Yilmaz H, Tasova Y, Alp E, Saba R, Caylan R, Bakir M, Akbulut A, Arda B, Esen S. Characteristics and analysis of risk factors for mortality in infective endocarditis. Eur J Epidemiol 2006; 21: 25-31.

23. Ostrowski S, Nowak D, Marcinkiewicz A, Kasielski M, Zwoliński R, Jaszewski R. Ocena skuteczności leczenia chirurgicznego pacjentów z infekcyjnym zapaleniem wsierdzia poprzez obserwację zmian wybranych markerów stanu zapalnego w okresie pooperacyjnym. Kardiochirurgia i Torakochirurgia Polska 2011; 8: 183-190.

24. Ostrowski S, Kasielski M, Kordiak J, Zwolinska A, Wlodarczyk A, Nowak D. Myocardial oxidative stress in patients with active infective endocarditis. Int J Cardiol 2013; 167: 270-276.

25. Jorge Sdo C, Caixeta AM, Abizaid A, Arnoni AS, Paulista PP, de Sousa LC, Magalhães HM, Piegas LS, Sousa JE. Infective endocarditis in children and adolescents. Arq Bras Cardiol 1994; 63: 173-177.

26. Chan KL, Embli JM. Endocarditis. Diagnosis and Management. Springer, London 2006, pp. 163-167.

27. Dieter RS. Coronary artery stent infection. Clin Cardiol 2000; 23: 808-810.

28. Elieson M, Mixon T, Carpenter J. Coronary stent infections. A case report and literature review. Tex Heart Inst J 2012; 39: 884-889.

29. Lombardi A, Coppola M, Pennica A, Maglio R, Moscaroli A, Lo Russo M, Provenza G. Splenic abscess due to Streptococcus anginosus. Case report. G Chir 2008; 29: 359-361. 